\title{
Cień złotych skrzydel. Polskie opcje napoleońskie w literaturze
}

Jacek Wójcicki 
nAPNS Seria XIII 2007

\section{Cień złotych skrzydeł. Polskie opcje napoleońskie w literaturze}

W dniach 22-23 października 2007 roku, z okazji 2()()-lecia utworzenia Księstwa Warszawskiego (którego konstytucję Napoleon zatwierdził 22 lipca 1807 roku — ta data dzienna znacząco zaważy jeszcze na polskiej historii...), odbyła się dwudniowa konferencja naukowa, poświęcona różnym aspektom obecności motywów napoleońskich w literaturze i kulturze polskiej, zarówno wczesnodziewiętnastowiecznej, jak późniejszej, aż do czasów obecnych. Część jej plonu składa się na główny zrąb niniejszego tomu „Napisu”.

Współorganizatorami konferencji były następujące instytucje i jednostki naukowe: Ośrodek Studiów Epoki Napoleońskiej Akademii Humanistycznej im. Aleksandra Gieysztora w Pultusku, Muzeum Romantyzmu w Opinogórze, Pracownia Literatury Okolicznościowej i Użytkowej Instytutu Literatury Polskiej Wydziałı Polonistyki Uniwersytetu Warszawskiego oraz Zespól Badań Obszarów Trzecich Literatury przy Pracowni Literatury II Połowy XIX Wicku Instytutu Badań Literackich Polskiej Akademii Nauk w Warszawie.

W poniedzialek 22 października 2007 roku obrady odbyły się w siedzibie gospodarza - Bibliotece Głównej Akademii I Iumanistycznej im. Aleksandra Gieysztora w Pultusku, w Gabinecie im. Wiktora i Juliusza Wiktora Gomulickich. Po oficjalnym otwarciu wygłoszono następujące referaty:

1. dr Ryszard Nowicki (Uniwersytet Kazinierza Wielkiego, Bydgoszcz), Wizennnek Napoleona u' śuietle "Mou') lurabi Skórzeuskiego" z $1809 \mathrm{r}$. Ireferat odczytany przez organizatora];

2. dr Anna Łysiak-Łątkowska (Uniwersytet Gdański), Opis epoki napoleoniskicj u' pamiętnikach Luizy Radziu'ittou'ej „Czterdzieści pię́ lat mojego życia (1770 do 1815)”;

3. dr Andrzej Nieuważny (Akademia Humanistyczna im. A. Gieysztora, Pułtusk), Żu'ot męczennika, czyli Śuiçta Helena po polsku; 
4. dr Dariusz Dybek (Uniwersytet Wrocławski), Polak - obyuntel nieba... Wojciecha Samina kazania z czasóu kościnszkou'skich i napoleoniskich;

5. dr Jacek Wójcicki (Instytut Badań Literackich PAN, Warszawa), Postau'y u'obec Napoleona u' poezji okolicznościon'ej środon'iska akademikón' krakouskich.

Po pierwszej części obrad odbyla się dyskusja. W części popoludniowej zaprezentowano wystąpienia:

6. dr Grzegorz Zając (Uniwersytet Jagielloński, Kraków), Napoleoniskie slady' w' twórczości Kazimierza Brodzińskiego;

7. dr Eligiusz Szymanis (Akademia Humanistyczna im. A. Gieysztora, Pułtusk), Cienie legendy' napoleonskicj u' tu'órzaśri Adama Mickicu'icza;

8. mgr Natalia Lipszyc (Uniwersytet Warszawski), Wątki napoleoniskie "w' wbranych tekstach Jacka Kaczmarskiego — próba interpretacji „Somosierr)” i „Kammanioli”;

9. dr Agnieszka Kruszyńska (Akademia Humanistyczna im. A. Gieysztora, Pultusk), Napoleon Waldemara Eysiaka. Wybranc aspekty tu'orzenia postaci bohatera "w "Szuańskicj balladzie";

10. dr Lech Giemza (Katolicki Uniwersytet Lubelski Jana Pawła II), „Czama” i „biata” legenda napoleoniska. O ponieści „Warunek” Eustachego Rylskiego.

Ożywiona dyskusja zakończyla również i tę część pierwszego dnia obrad.

Drugi dzicń obrad (wtorek 23 paździennika 2007) odbył się w Muzeum Romantyzmu w Opinogórze. Wygłoszono następujące referaty:

1. prof. dr hab. Marian Skrzypek (Instytut Filozofii i Socjologii PAN, Warszawa), "Promemoria Bommaparcie" - antynapoleoniska broszura Syluain Maréchala;

2. prof. dr hab. Zbigniew Chojnowski (Uniwersytet Warmińsko-Mazurski, Olsztyn), Napoleon i jego wojska "'oczach Mazuróu;

3. dr Tomasz Ślęczka (Uniwersytet Wrocławski), Rosja i jej mieszkanicy "' oczach polskich jericóu' "rojennych XI'TI i początón' XIX urieku;

4. dr Krzysztof Ostrowski (Akademia Mlumanistyczna im. A. Gieysztora, Pułtusk), Napoleon "' polskich lożach masoniskich.

Po dyskusji nad zaprezentowanymi wystąpieniami uczestnicy spotkania zwiedzili Muzeum Romantyzmu pod kierunkiem jego długoletniego dyrektora Janusza Królika, a następnie przez obecnego dyrektora Romana Kochanowicza zostali podjęci poczęstunkiem, podczas którego w miłej i koleżeńskiej atmosferze dokonano podsumowania i zamknięcia obrad. Uczestnicy konferencji podkreślali zarówno wage poznawczą przedstawionych referatów, jak i sprawność organizacyjną i życzliwość gospodarzy. Należy tu z wdzięcznością wspomnieć zarówno Dyrekcję Ośrodka Studiów Epoki Napoleońskiej w osobie dra Krzysztofa Ostrowskiego, jak i Administrację tej jednostki 
w osobie Pani Elzbiety Brengos, dzięki której staraniom pobyt grupy uczestników konferencji w Pultusku i Opinogórze był zorganizowany perfekcyjnic.

„O, roku ów!” - chciałoby się zawolać za wieszczem, mając na myśli rok 1807 — także pełen nadziei, jeszcze niezawiedzionych. Spoleczeństwo polskie wprawdzie nie widziało wówczas zdarzeń tak spektakularnych jak zwycięstwa rodaków nad austriackimi najeźdźcami dwa lata później, ani tak powszechnie przejmujących serca i umysły jak Mickiewiczowski „rok urodzaju”, „rok wojny”, niestety także rok wielkiej klęski, słowem: 1812. Niemniej to wlaśnie dokładnie wtedy „bóg wojny” zstąpił na naszą ziemię... i od tego momentu w odniesieniu do naszego bytu narodowego i samoświadomości zaczęło się — co prawda nie „wszystko”, nie w takiej kosmicznej skali, jak pragnęli tego panegiryści, przypisujący Napolconowi boską moc sprawczą, lecz niewątpliwie - bardzo wiele.

Zapraszamy serdecznie do lektury. 